\title{
The Satiating Effect of NUTRALYS $®$ Pea Protein Leads to Reduced Energy intake in Healthy Humans
}

\author{
Roberta $\mathrm{Re}^{1}$, Sonia Pombo ${ }^{1}$, Wim Calame ${ }^{2}$, Catherine Lefranc-Millot ${ }^{3}$ and Laetitia Guérin-Deremaux ${ }^{3 *}$ \\ ${ }^{1}$ Leatherhead Food Research, Randalls road, Leatherhead, Surrey, KT227RY, UK \\ ${ }^{2}$ Statistical BV, Wassenaar, The Netherlands \\ ${ }^{3}$ Roquette, 62080 Lestrem, France
}

Received: June 02, 2016; Accepted: July 10, 2016; Published: August 08, 2016

*Corresponding author: Laetitia Guérin-Deremaux, Msc, Roquette, Nutrition \& Health R\&D, 62080 Lestrem, France, Tel: +33 (0)3 21 63 38 40; Fax: +33 (0)3 216394 10; E-mail address: laetitia.guerin-deremaux@roquette.com

\begin{abstract}
Background and purpose: Global obesity epidemic is still a major and growing public health concern. Product reformulation favoring satiety can promote weight control, specifically achievable through increasing the protein content of food. Until now, main studies evaluating the impact of proteins on satiety and caloric intake have focused on animal-based sources such as whey proteins. Moreover, in the context of searching for sustainable alternatives to animal proteins, pea proteins offer huge advantages potentially driving to an increase of its use in food products. In this context, in a four-arm, double-blind, randomized, cross-over, pilot study, the short-term satiating effects of two doses of a plant-based protein isolate, NUTRALYS $®$ pea protein $(30 \mathrm{~g}$ and $15 \mathrm{~g})$ in comparison to whey protein $(30 \mathrm{~g})$ and a no protein control, were investigated using vegetable soup as a carrier.
\end{abstract}

Methods: Participants $(n=33)$ consumed the test products in preload soups, and their impact on post-prandial satiety was evaluated for three hours by measuring: energy intake at a subsequent ad libitumlunch, subjective food intake Visual Analogue Scale (VAS) ratings and, for a subset of participants ( $n=9$ ), plasma levels of glucose, insulin, GLP-1, PYY and CCK.

Results: Compared to the control, all other protein-containing soups resulted in significantly lower energy intake at the ad libitum meal, with no differences between themselves. Overall, results from the VAS satiety ratings were not all consistent with intake at this meal. Yet there was a trend for higher ratings of fullness for the $30 \mathrm{~g}$ of pea protein group compared to the control. In addition, the soup containing $30 \mathrm{~g}$ of whey protein significantly reduced feelings of hunger. Area Under the Curve (AUC) values for glucose and insulin responses following the control soup were significantly greater than for the other protein soups. AUC values for GLP-1, and PYY responses did not significantly differ between soupsv. A trend for higher AUC values for CCK following $30 \mathrm{~g}$ of pea protein compared to control was observed.

Conclusions: These results demonstrate that the plant based pea protein isolate and the whey protein equally reduce energy intake, making NUTRALYS $®$ pea protein a high quality alternative to animal protein.

Keywords: Pea Protein; Whey Protein; Energy Intake; Satiety; Gastrointestinal Peptides

\section{Introduction}

As the global obesity epidemic and its related noncommunicable diseases, continue to be a major public health issue [1], the food industry is increasingly being encouraged to contribute to the alleviation of the obesity burden through product reformulation and the development of the next generation of foods [2]. One strategy involves increasing the satiating power of foods and beverages, reducing consumption quantity, and thus energy intake, promoting weight loss $[3,4]$. This can easily be achieved through increasing the amount of protein consumed, as gram for gram, protein is the most satiating macronutrient, in comparison to fat and carbohydrate [5]. However, the variety of protein types and sources are vast, and as of yet the optimal source of protein for satiety, be it from either animal or plant, remains the subject of much debate and study.

For example, in protein source comparison studies [6], it has been found no difference between soy, whey or gluten protein, however whey and soy protein have both been shown to reduce ad libitum energy intake compared to egg albumin in another study [7]. Yet, in disagreement with these results, Lang et al. [8] found egg albumin, casein, gelatin, soy protein, pea protein, and wheat gluten did not differ in their satiating capacity. Even within protein types, there is debate and data variation. For example human studies have shown, in animal protein studies, fish protein was found to be more satiating than beef or chicken [9], and in dairy proteins studies, that whey protein is significantly more satiating than casein $[10,11]$ but conversely this has not been supported by other studies [6]. As such it is apparent that research within the area of 'protein and satiety' remains in conclusive, highly debated and greater research is required investigating and comparing protein types and sources to generate clarity within the research field.

The disparity between the satiety effects of different protein sources has been concluded to be partly linked to the 
compositional differences in circulating amino acids derived from protein digestion[12], which in turn, directly and indirectly affects the degree of appetite related hormone secretion. This is thought to be attributed to the Branched Chain Amino Acid (BCAA) content of the specific protein [13, 14]. For example, leucine is known to contribute to satiety, through stimulating leptin secretion [15]. Also, the tryptophan content of proteins may be important for satiety enhancement $[9,16]$, as tryptophan has been highlighted to have a role in the synthesis of serotonin, which can modulate satiety [17]. Histidine content of protein may also contribute to satiety, as evidenced in animal studies [18], due to its involvement in the synthesis of the anorexigenic neurotransmitter, histamine [19].

The difference between protein sources on appetite hormone response is exemplified in studies of dairy proteins, which produce a greater insulinaemic response than fish or soya protein, and, within dairy proteins, whey producing greater insulin levels than casein [20]. Additionally, whey, soy and gluten proteins have been shown to result in extended duration and peak secretion of Glucagon-like peptide-1 (GLP-1) [6], while intact milk protein elevates Cholecystokinin (CCK) more than whey and pea protein hydrolysates [21]. Given that animal derived protein sources, such as dairy proteins, contain the highest levels of BCAA, tryptophan and histidine, among all other sources of protein [22], it is not surprising that dairy and other animal derived protein sources are so satiating.

Pea protein is a high quality alternative to animal derived proteins, with similar protein digestibility [23]. However pea protein additionally offers other potential health benefits, including the prevention of infection in the gastrointestinal tract [24], reducing circulating levels of lipids [25] and reducing hypertension [26,27]. Replacing animal derived proteins with pea protein also has economic and sustainability advantages, in aiding the reduction of global warming, eutrophication, acidification and land use [28]. Due to these various and distinct advantages, the use pea protein within product formulation is expected to increase. Its bioavailability of amino acids and digestibility, similar to those of animal and dairy protein, also highlights its potential to enhance the satiety effects of food products to the same or greater intensity as these proteins. However, the satiety value of pea protein is not well characterized: only one study examined the impact of an hydrolysate form of pea protein on satiety [21] and another study compared pea protein with egg albumin, casein, gelatin, soy protein and wheat gluten, in terms of satiety, but only by measuring glucose and insulin response, and not the response of satiety related hormones [8]. As such, there is insufficient conclusive literature concerning pea proteins effect on satiety evaluated in humans in comparison to other protein source types, especially those derived from animal sources.

The present study investigated the satiating effect of vegetable soups enriched either with pea protein (15g or $30 \mathrm{~g}$ ) or with whey protein (30g), in a dose dependent manner, or with no added protein (control soup). Satiety was evaluated quantitatively via intake measures at an ad libitum test meal, and also, within a subset of participants, via satiety related hormone concentrations
(Insulin, Glucose, Peptide YY (PYY), Cholecystokinin (CCK) and Glucagon-like Peptide-1 (GLP-1)), and qualitatively via subjective food intake Visual Analogue Scale (VAS) satiety ratings.

\section{Methods}

\section{Participants}

Thirty-six volunteers were recruited from Leatherhead Food Research's database and through adverts placed in local papers, shops and companies in Leatherhead, Surrey, UK. A total of 33 volunteers completed the study, 3 withdrawing for personal reasons, not related to the study. To participate in the study, participants had to meet the following criteria: age $\geq 18$ and $\leq 65$ years; $\mathrm{BMI} \geq 18.5$ and $\leq 25.0 \mathrm{~kg} / \mathrm{m}^{2}$; apparently healthy; strenuous exercise $\leq 10$ hours per week; consumption of $\leq 14$ alcohol units a week (women) or $\leq 21$ alcohol units a week (men); non-smoker; not currently pregnant or having been pregnant in the six months prior to pre-study investigation; no reported lactation six weeks before pre-study investigation; no reported participation in night shift work from two weeks prior to prestudy investigation until the end of the study; no reported weight loss or gain $\geq 10 \%$ of bodyweight during a period of six months; not participating in or using any medically or self-prescribed diet or diet products one month prior to the study, or the intention to use any kind of diet during the study; no eating disorders as measured by the SCOFF questionnaire with $\geq 2$ "yes" responses [29]; not a highly restrained, emotional or environmental eater as measured by a score $\geq 3$ for Dutch Eating Behavior Questionnaire [30]. This study was conducted according to the guidelines in the Declaration of Helsinki and all procedures involving human subjects were approved by the South East Coast Research Ethics Committee (REC ref: 11/L0/0642). The test cohort was made up of 10 male and 23 female participants, with an average age of 42.2 \pm 15.5 years and a BMI of $22.2 \pm 3.8 \mathrm{~kg} / \mathrm{m} 2$ (Table 1 ). Of these, a subset of 9 volunteers ( 5 men and 4 women) with an average age of $41.9 \pm 13.9$ years and a BMI of $22.6 \pm 1.1 \mathrm{~kg} / \mathrm{m} 2$ was used to assess satiety related hormone concentrations through intravenous blood collection. Written informed consent was obtained from all subjects prior to the commencement of the study.

\section{Study design}

A four arm, double blind randomized cross-over design was used to investigate the satiating effects of four soup preloads (15g pea protein, $30 \mathrm{~g}$ pea protein, $30 \mathrm{~g}$ whey protein and a no protein added control). Ad libitum test meal intake, glucose, insulin, gut hormones (GLP-1, PYY and CCK) and subjective food intake ratings were used to assess satiety. Food intake VAS questions were recorded via electronic Visual Analogue Scales (VAS) on hand held computers [31] and included "how full do you feel?", "how hungry do you feel?", "how much do you think you can eat?" and "how strong is your desire to eat?", and were end anchored with "not at all" (scored as 0) and "Extremely" (scored as 100).

Participants attended four separate test days in a randomized order, with a one week wash-out period between test days. Prior to each test day, volunteers were asked to maintain their normal lifestyle, abstain from alcohol and vigorous exercise for 24 hours 
Table 1: Characteristics of participants that completed the satiety study and blood collection.

\begin{tabular}{|c|c|c|c|c|c|c|c|c|}
\hline & \multicolumn{4}{|c|}{ Satiety } & \multicolumn{4}{|c|}{ Blood collection } \\
\hline & \multicolumn{2}{|c|}{ Men } & \multicolumn{2}{|c|}{ Women } & \multicolumn{2}{|c|}{ Men } & \multicolumn{2}{|c|}{ Women } \\
\hline \multirow[t]{2}{*}{$N$} & \multicolumn{2}{|c|}{10} & \multicolumn{2}{|c|}{23} & \multicolumn{2}{|c|}{5} & \multicolumn{2}{|c|}{4} \\
\hline & Mean & SD & Mean & SD & Mean & SD & Mean & SD \\
\hline Age (years) & 38 & 16 & 44 & 15 & 36 & 12 & 43 & 13 \\
\hline $\operatorname{BMI}\left(\mathrm{kg} / \mathrm{m}^{2}\right)$ & 22.2 & 1.5 & 22.2 & 1.6 & 22.6 & 2.0 & 22.7 & 0.8 \\
\hline SCOFFa & 0.0 & 0.0 & 0.1 & 0.2 & 0.0 & 0.0 & 0.0 & 0.0 \\
\hline $\begin{array}{c}\text { DEBQ restrained eating } \\
\text { score }^{\mathrm{b}}\end{array}$ & 1.9 & 0.4 & 1.8 & 0.5 & 2.1 & 0.4 & 1.7 & 0.4 \\
\hline $\begin{array}{c}\text { DEBQ emotional eating } \\
\text { score }^{\mathrm{b}}\end{array}$ & 1.3 & 0.4 & 1.8 & 0.7 & 1.5 & 0.6 & 1.9 & 0.4 \\
\hline $\begin{array}{l}\text { DEBQ environmental } \\
\text { eating score }\end{array}$ & 2.3 & 0.5 & 2.5 & 0.5 & 2.4 & 0.6 & 2.5 & 0.5 \\
\hline
\end{tabular}

SCOFF, Sick, Control, One stone, Fat, Food. DEBQ, Dutch Eating Behaviour Questionnaire. aParticipants with a score greater than two for the SCOFF questionnaire were excluded. ${ }^{b}$ Participants with a score greater than three for any component of the DEBQ were excluded from the study.

and consume their evening meal no later than 20.00, and repeat this before each subsequent test visit. Drinking after 20.00 was allowed but restricted to only water up until one hour prior to the start of the study day when no fluids were allowed. On the test day, participants were instructed to arrive at 07.45 , and baseline ratings of satiety, via VAS, and intra-venous blood samples, for satiety hormone analysis, were collected prior to consumption of breakfast at 08.00 . On their first visit, participants were asked to pour their own habitual portion of cereal and milk; this was measured and then replicated at subsequent visits. Participants were also provided with $200 \mathrm{ml}$ of their habitual morning drink (black coffee/tea/water) to avoid caffeine withdrawal effects. They were seated in booths to ensure participant isolation and given 15 minutes to consume the whole breakfast. Immediately post consumption, Food intake VAS questions were completed, after which the volunteers were free to leave the booths and take a seat in the waiting area where they remained throughout the test day. Consumption of water was allowed during this time; however, consumption was restricted to $150 \mathrm{ml}$ every hour in the morning. To ensure similar conditions existed during each test day, consumption of water during the first test was recorded and repeated at each subsequent test. Moreover, the mode of transportation was also recorded and kept constant across sessions for each volunteer.VAS questions were asked every 30 minutes until immediately prior to the consumption of the soup test preload. In a subset of participants $(n=9), 20$ minutes prior to the consumption of the soup preload (baseline) and then every 20 minutes following consumption of the soup, for the following 3 hours, blood samples were taken for the analysis of glucose, insulin and GLP-1, PYY and CCK. 3 hours after the breakfast, participants returned to the booths and were provided with a portion of the soup preload (see test products section), which they had to completely consume within 20 minutes, from a bowl using a spoon. Immediately post consumption, Food intake VAS were presented, after which the participants were free to leave the booths and return to the waiting area. Food intake VAS were then presented at 20 minutes intervals until the consumption of the ad libitumlunch meal three hours after the consumption of test product. The ad libitum lunch meal consisted of 2 kilograms of white penne pasta with cheese and tomato sauce $(5.23 \mathrm{~kJ} / \mathrm{g}$ or $1.25 \mathrm{kcal} / \mathrm{g}$ ), served in 1 portion in a large foil tray. Participants were given 30 minutes to consume the lunch and were instructed to eat until they were comfortably full. They were also given water $(150 \mathrm{ml})$ and instructed to consume the full amount. Immediately post consumption of the lunch, Food intake VAS was presented, after which the participants were free to return to the waiting area. Food intakes VAS then were presented 30 minutes after the lunch, after which the participants were free to leave.

\section{Test products}

Powdered vegetable soup (Roquette, France) was used as a vehicle for all 4soup preloads provided in this study. All 4 preloads had a similar energy content ( $200 \mathrm{kcal}$, adjusted viamaltodextrin addition), of equal volume $(300 \mathrm{ml} /$ portion) and contained either 1)no added protein (control), or 2) $15 \mathrm{~g}$ NUTRALYS $®$ pea protein, 3) 30g NUTRALYS $®$ pea protein or 4 ) $30 \mathrm{~g}$ whey protein (Table 2).The amino acids composition of the 2 types of proteins are shown in Table 3. The pea protein used was NUTRALYS ${ }^{\circledR}$ pea protein (Roquette, France), a highly purified vegetable protein isolate, from the yellow pea (Pisum sativum), containing $85 \%$ protein, $7 \%$ fat, $3 \%$ carbohydrate, and $5 \%$ ash on a dry matter basis. Each soup portion was prepared by the manufacturer and delivered to the study centre at Leatherhead Food Research with a randomly assigned code, in order to blind the study staff and participants from the identity of the product. All products were stored at room temperature and prepared on the study day by mixing $55 \mathrm{~g}$ of powdered vegetable soup with $300 \mathrm{ml}$ water and heating the soup in a microwave for 90 seconds.

\section{Blood collection and analysis}

Blood samples were collected via intra-venous cannula into either heparin tubes for glucose analysis or EDTA tubes for hormone analysis (Sigma Aldrich, Poole, $500 \mathrm{kIU} / \mathrm{ml}$ blood) and centrifuged at $1200 \mathrm{x} \mathrm{g}$ for 10 minutes. The resulting plasma was then stored at $-80^{\circ} \mathrm{C}$ until analysis. Blood glucose was measured using a glucose analyser (YSI, Ohio) with a sensitivity of $0-50 \mathrm{mmol} / \mathrm{L}$ and a margin of error of $\pm 2 \%$. Human insulin, total PYY, GLP-1 ELISA kits were purchased from Millipore (USA) 
Table 2: Nutritional composition, per 55g portion of the test soup containing either no added protein (control), $30 \mathrm{~g}$ of whey protein, and $15 \mathrm{~g}$ or $30 \mathrm{~g}$ of pea protein.

\begin{tabular}{|l|c|c|c|c|}
\hline & Control & Whey protein & Pea protein (15g) & Whey protein (30g) \\
\hline Energy (kJ/kcal) & $834.0 / 199.3$ & $822.0 / 196.4$ & $851.0 / 203.4$ & $874.0 / 208.9$ \\
\hline Total Protein(g) & 2.5 & 32.1 & 17.5 & 32.5 \\
\hline Pea protein (g) & - & - & 15.0 & 30.0 \\
\hline Whey protein (g) & & 29.6 & - \\
\hline Carbohydrates (g) & 45.6 & 10 & 28.7 & 12.1 \\
\hline with sugars (g) & 3.9 & 5.3 & 3.4 & 3.0 \\
\hline Lipids (g) & 0.2 & 2.1 & 1.5 & 2.8 \\
\hline saturated (g) & 0.1 & 0.9 & 0.2 & 0.4 \\
\hline Dietary fibres (g) & 0.9 & 3.3 & 1.1 & 1.3 \\
\hline Sodium (mg) & 744.0 & 1064.0 & 926.0 & 1107.0 \\
\hline Potassium (mg) & 65.0 & 153.0 & 129.0 & 193.0 \\
\hline Calcium (mg) & 20.0 & 110.0 & 29.0 & 37.0 \\
\hline Phosphorus (mg) & 21.0 & 127.0 & 221.0 & 418.0 \\
\hline Magnesium (mg) & 4.0 & 19.0 & 19.0 & 34.0 \\
\hline
\end{tabular}

Table 3: Amino acids composition (g) for $100 \mathrm{~g}$ of NUTRALYS ${ }^{\circledast}$ pea protein or whey protein.

\begin{tabular}{|c|c|c|}
\hline & NUTRALYS $^{\circledR}$ pea protein & $\begin{array}{l}\text { Whey protein } \\
\text { concentrate }\end{array}$ \\
\hline Alanine & 3.3 & 4.1 \\
\hline Arginine & 6.6 & 2.1 \\
\hline Aspartic acid & 8.9 & 8.7 \\
\hline Cystine & 0.8 & 1.9 \\
\hline Glutamic acid & 13.2 & 13.9 \\
\hline Glycine & 3.1 & 1.5 \\
\hline Histidine & 1.9 & 1.5 \\
\hline Isoleucine & 3.7 & 4.9 \\
\hline Leucine & 6.4 & 8.6 \\
\hline Lysine & 5.7 & 7.2 \\
\hline Methionine & 0.8 & 1.6 \\
\hline Phenylalanine & 4.2 & 2.6 \\
\hline Proline & 3.4 & 4.7 \\
\hline Serine & 3.9 & 4.2 \\
\hline Threonine & 2.8 & 5.7 \\
\hline Tryptophan & 0.7 & 1.5 \\
\hline Tyrosine & 3.1 & 2.8 \\
\hline Valine & 4.0 & 4.6 \\
\hline
\end{tabular}

and CCK ELISA kits, determining the bioactive CCK-8 form, from Phoenix Pharmaceuticals (USA); all analyses was performed according to manufacturer's instructions.

\section{Statistical analysis}

This study was powered based on a previous intervention study carried out at Leatherhead Food Research (unpublished findings), in which the satiating effects of $48 \mathrm{~g}$ of pea protein was compared with other sources of protein. Based on this, the power analysis [32] revealed that a study population of 36 individuals would be needed in order to find a significant ( $p<0.05)$ difference in VAS score between both proteins with a power of $80 \%$ by two-sided testing. Statistical analysis of the outcomes of this study was performed using STATA, version 10 (StataCorp LP, College Station, Texas, US) for Windows. Normality of the data was assessed using Shapiro-Wilk test. The outcome of energy intake at the ad libitum meal was analysed via paired t-testing. The results at the various time intervals with respect to the VAS scores was subtracted (resulting in delta results) from the paired observation as obtained at the start of the intervention (baseline) to account for differences at the start and to minimise intervariation. The consumption of the test soup product at 11.00 was taken as the starting baseline value $(\mathrm{t}=0)$, and the consumption of the ad libitum meal, 3 hours later, was considered the end $(t=180)$. The results were analysed using Analysis Of Variance (ANOVA), fitting the model by F-test and stepwise dummy multiple regression. For glucose, insulin, PYY, GLP and CCK, the outcome per person at the start of the study was subtracted from the outcome at the various intervals in order to minimize the inter-variation (high- versus low-responder) between the participants. Since the starting values were almost similar for all persons, for glucose and insulin only the absolute outcome were analysed. The area under the time curve per person per variable was calculated according to the trapezoid rule. Accordingly, the outcome of the total area under the time curve was evaluated (two by two) either via paired t-test or via Wilcoxon matchedpairs signed-rank test dependent on the distribution in outcome. In some cases, where clear peak values in the area under the time concentration values were established, the same approach was followed for peak evaluation.

To evaluate a potential gender effect on the changes in VAS scores, General Estimating Equations (GEE, Gaussian distribution) was used with gender as the independent factor, 
applying a repeated design structure, and treatment, time and interaction as other independent factors. The same methodology was used to detect any impact by gender on the amount of food consumed during the ad libitum meal, with gender and product as independent factors and the total grams of food eaten as dependent. Throughout the study, a p-value of 0.05 was considered to identify a significant difference, using two-sided testing.

\section{Results}

\section{Ad libitum energy intake}

Energy intake at the ad libitum meal was significantly higher following consumption of the control soup (no added protein), than following consumption of the soup with $30 \mathrm{~g}$ of whey protein $(\mathrm{p}<0.01)$, the soup with $15 \mathrm{~g}$ of pea protein $(\mathrm{p}<0.05)$ and the soup with30g of pea protein ( $\mathrm{p}<0.001)$, by $441.4 \mathrm{~kJ} / 105.5 \mathrm{kcal}, 287.9$ $\mathrm{kJ} / 68.8 \mathrm{kcal}$ and $409.6 \mathrm{~kJ} / 97.9 \mathrm{kcal}$ respectively (Table 4). There were no significant differences in ad libitum meal consumption between the products containing added protein (all $p>0.05$ ).

\section{Food intake VAS scores}

Following consumption of the test products, a significant ( $p$ $<0.001$ ) time-dependent decrease in Food intake VAS questions were observed for "how full do you feel?", "how hungry do you feel?", "how much do you think you can eat?" and "how strong is your desire to eat?" (Figure 1).For the question, "how full do you feel?", the control preload was reported to be equally as filling as the soups containing $15 \mathrm{~g}$ of pea protein and $30 \mathrm{~g}$ of whey protein ( $p>0.05$ ), with a trend for it being less filling than the soup containing $30 \mathrm{~g}$ of pea protein, but this did not reach statistical significance $(\mathrm{p}=0.058)$. The soup containing $30 \mathrm{~g}$ of pea protein was perceived to be more filling than soup containing $15 \mathrm{~g}$ of pea protein $(p<0.05)$, and ratings for the other soups did not significantly differ $(\mathrm{p}>0.05)$.For the question "how hungry do you feel?", the soup containing $30 \mathrm{~g}$ of whey protein, significantly reduced feelings of hunger compared to the control soup ( $\mathrm{p}<$ 0.05 ) and the soup with $30 \mathrm{~g}$ of pea protein $(\mathrm{p}<0.01)$, but not compared to the soup with $15 \mathrm{~g}$ of pea protein ( $p>0.05$ ); no other soups differed from the control or from each other in subjective feelings of hunger ( $p>0.05)$. Responses to the question "how much do you think you can eat?" indicated that following the control soup participants believed they could eat significantly less than following the soup with $15 \mathrm{~g}$ of pea protein $(\mathrm{p}<0.05)$, with the soups with $30 \mathrm{~g}$ of added whey or pea protein not differing from control (both $\mathrm{p}>0.05$ ). Furthermore, participants anticipated that they would eat less following the soup with $30 \mathrm{~g}$ of whey protein compared to the soups with $15 \mathrm{~g}(\mathrm{p}<0.001)$ or $30 \mathrm{~g}$ of pea protein $(\mathrm{p}<0.05)$. In response to the question "how strong is your desire to eat?", participants reported comparable desire to eat following all test foods ( $p>0.05$ ), except from a lower desire to eat being shown following $30 \mathrm{~g}$ whey protein compared to $15 \mathrm{~g}$ of pea protein.

Both the change in VAS scores and the grams of food intake were analysed for a potential gender effect. With respect to the former, a significant effect by gender was observed: women showing significantly $(\mathrm{p}<0.01)$ higher changes in feelings of satiety, which resulted in higher changes in the perception of feeling full and lower in the those of feeling hungry, of how much one can eat and of desire to eat, compared with men. This was found in all combinations tested, except for "How hungry do you feel?", "How much can you eat?", and "How strong is your desire to eat?" when comparing the soup with $15 \mathrm{~g}$ of pea protein and the soup with $30 \mathrm{~g}$ of pea protein. With respect to the grams consumed during the ad libitum meal, a significant gender effect was noted too: women showed greater sensitivity to the various test products, on the amount of food consumed, compared to men $(p<0.01)$, resulting in a higher reduction of total amount consumed. Moreover, the absolute amount of food eaten by men was significantly $(\mathrm{p}<0.005)$ higher than that by women.

\section{Glucose and insulin response to test products}

Consumption of the control soup resulted in the greatest peak plasma glucose $(6.90 \pm 1.35 \mathrm{mmol} / \mathrm{L}$ at 40 minutes $)$ while the soup with $15 \mathrm{~g}$ of pea protein led to a peak of $5.8 \pm 0.84 \mathrm{mmol} / \mathrm{L}$ after 20 minutes and neither the soup with $30 \mathrm{~g}$ of pea nor whey protein yielded an apparent plasma glucose peak (Figure 2a). The

Table4: Energy intake of an ad libitum meal 3 hours after the consumption of test soup containing either no added protein (control), $30 \mathrm{~g}$ of whey protein, $15 \mathrm{~g}$ of pea protein or $30 \mathrm{~g}$ of pea protein.

\begin{tabular}{|c|c|c|c|c|}
\hline & Control & $\begin{array}{c}\text { Whey } \\
\text { protein } \\
\mathbf{( 3 0 g )}\end{array}$ & $\begin{array}{c}\text { Pea } \\
\text { protein } \\
\mathbf{( 1 5 g )}\end{array}$ & $\begin{array}{c}\text { Pea protein } \\
\mathbf{( 3 0 g )}\end{array}$ \\
\hline $\begin{array}{c}\text { Mean (kJ/ } \\
\text { kcal) }\end{array}$ & 3975.6 & $3534.2 /$ & $3687.8 /$ & $3566.0 /$ \\
\hline $950.2^{\mathrm{abc}}$ & $844.7^{\mathrm{a}}$ & $881.4^{\mathrm{b}}$ & $852.3^{\mathrm{c}}$ \\
\hline SEM (kJ/kcal) & $234.7 / 56.1$ & $225.1 / 53.8$ & $\begin{array}{c}231.2 / \\
55.3\end{array}$ & $199.6 / 47.7$ \\
\hline
\end{tabular}

Common superscript letters between 2 groups denote significantly different values $(\mathrm{p}<0.05, \mathrm{n}=33)$. SEM: standard error of the mean.
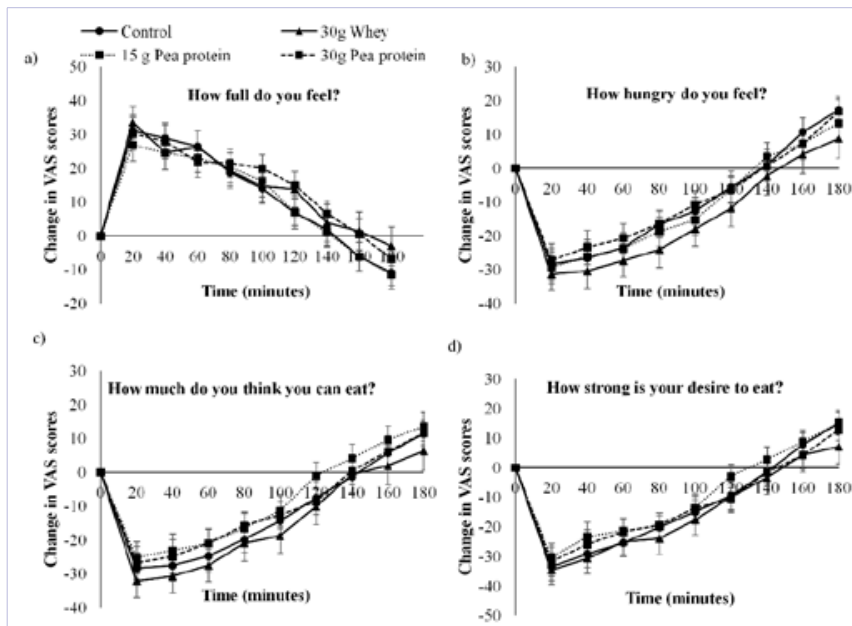

Figure 1: Change from baseline VAS scores for questions; (a) how full do you feel?, (b) how hungry do you feel?, (c) how much do you think you can eat?, (d) how strong is your desire to eat?, after the consumption of test product $(T=0)$ containing either no protein (control), $30 \mathrm{~g}$ whey protein, $15 \mathrm{~g}$ pea protein or $30 \mathrm{~g}$ pea protein. Data is mean $\pm 1 \mathrm{x}$ SEM, $n=33$. 
AUC for the control soup was significantly greater than all other soups with added protein $(\mathrm{p}<0.05)$ and there were no significant differences between the plasma glucose AUC between the other test products (Table 5).

A similar trend was seen for the insulin response, with both the control and soup with $15 \mathrm{~g}$ of pea protein resulting in peak insulin plasma concentrations of $21.48 \pm 2.08 \mu \mathrm{U} / \mathrm{ml}$ at 60 minutes and $18.14 \pm 3.18 \mu \mathrm{U} / \mathrm{ml}$ at 40 minutes, respectively (Figure $2 \mathrm{~b}$ ). Consumption of the soup containing $30 \mathrm{~g}$ pea protein resulted in a comparatively reduced peak insulin concentration at 40 minutes of $10.42 \pm 1.84 \mu \mathrm{U} / \mathrm{ml}$, while the soup containing $30 \mathrm{~g}$ of whey protein did not result in a peak over the time samples were collected. Statistical comparison of plasma insulin AUC after consumption of the test products (Table 5) demonstrated that insulin levels were significantly greater for the control compared to all other test products ( $\mathrm{p}<0.05)$. Additionally, the AUC for plasma insulin after the consumption of soup containing pea protein $(15 \mathrm{~g}$ and $30 \mathrm{~g})$ was significantly greater than for soup containing whey protein (both $\mathrm{p}<0.05$ ), while consuming $30 \mathrm{~g}$ of pea protein resulted in significantly lower insulin AUC compared to $15 \mathrm{~g}$ of pea protein $(\mathrm{p}<0.05)$ (Table 5$)$.

\section{GLP-1, CCK-1 and PYY response to test products}

Consumption of the test products containing $30 \mathrm{~g}$ whey and $30 \mathrm{~g}$ pea protein resulted in a peak plasma concentration of GLP-1 of $2.53 \pm 0.54 \mathrm{pmol} / \mathrm{L}$ at 80 minutes and $2.30 \pm 0.24$ pmol/ L at 100 minutes, respectively. Overall consumption of these test products resulted in sustained and increased levels of GLP-1 over the whole duration of sample collection (3 hours) compared with that of the control or $15 \mathrm{~g}$ pea protein (Figure 2d), which returned to baseline at 120 minutes and 100 minutes,
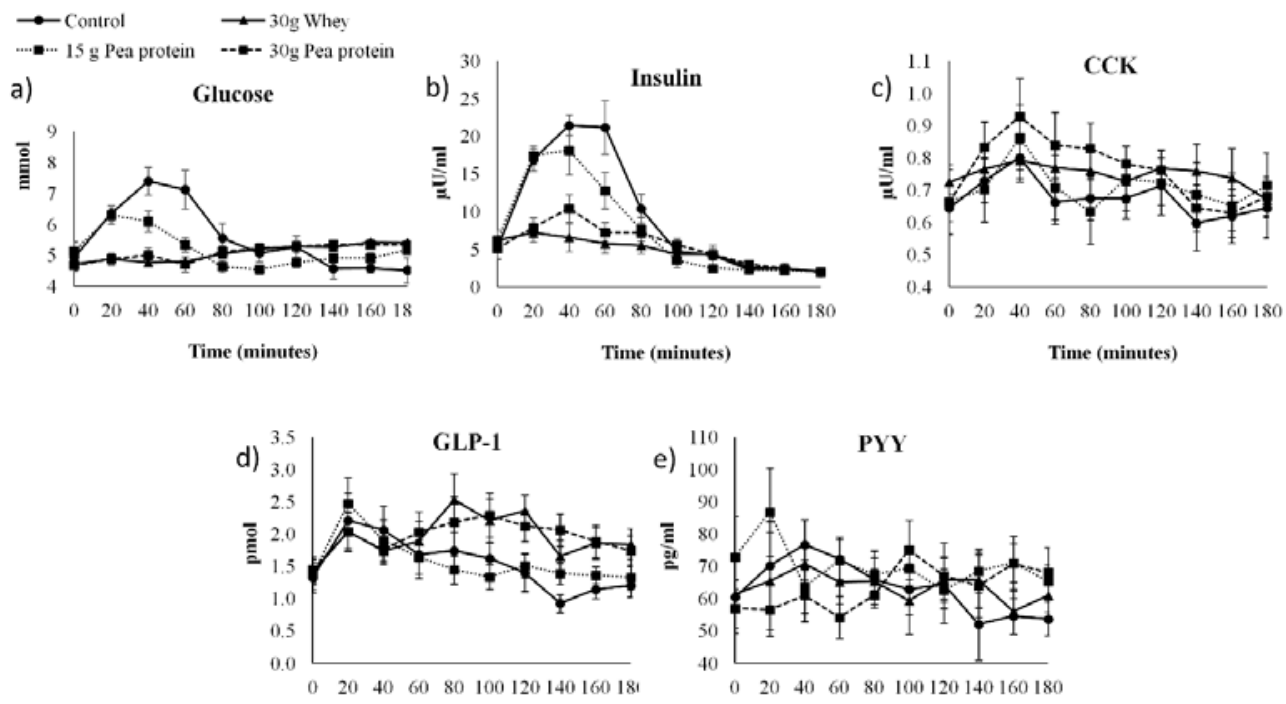

Time (minutes)

Time (minutes)

Figure 2: Plasma levels of (a) glucose, (b) insulin, (c) CCK (d) GLP-1 (e) PYY after the consumption of test product (T=0)containing either no protein (control), $30 \mathrm{~g}$ whey protein, $15 \mathrm{~g}$ pea protein or $30 \mathrm{~g}$ pea protein. Data is mean $\pm 1 \times \mathrm{SEM}, \mathrm{n}=9$.

Table 5: AUC for plasma glucose, insulin, CCK, GLP-1 and PYY over 180 minutes after the consumption of test product containing either no protein (control), $30 \mathrm{~g}$ of whey protein, $15 \mathrm{~g}$ of pea protein or $30 \mathrm{~g}$ of pea protein.

\begin{tabular}{|c|c|c|c|c|c|c|c|c|}
\hline & \multicolumn{2}{|l|}{ Control } & \multicolumn{2}{|c|}{ Whey protein } & \multicolumn{2}{|c|}{ Pea protein (15g) } & \multicolumn{2}{|c|}{ Pea protein $(30 \mathrm{~g})$} \\
\hline & Mean & SEM & Mean & SEM & Mean & SEM & Mean & SEM \\
\hline $\begin{array}{c}\text { Glucose }(\mathrm{mmol} / \mathrm{L} \cdot 180 \\
\mathrm{min})\end{array}$ & $915.5^{\mathrm{abc}}$ & 25.4 & $827.2^{\mathrm{a}}$ & 21.2 & $842.8^{\mathrm{b}}$ & 19.6 & $830.0^{c}$ & 22.6 \\
\hline $\begin{array}{l}\text { Insulin }(\mu \mathrm{U} / \mathrm{ml} \cdot 180 \\
\text { min) }\end{array}$ & $1836.5^{\mathrm{abc}}$ & 132.2 & $858.2^{\mathrm{ad}}$ & 85.2 & $1427.2^{\mathrm{bd}}$ & 166.9 & $1039.8^{c d}$ & 119.9 \\
\hline CCK (ng/ml180 min) & 122.5 & 8.8 & 134.0 & 10.2 & 131.3 & 8.4 & 139.3 & 9.6 \\
\hline $\begin{array}{l}\text { GLP-1 (pmol/L·180 } \\
\text { min) }\end{array}$ & 288.6 & 45.0 & 358.3 & 55.6 & 284.9 & 34.9 & 361.9 & 38.9 \\
\hline PYY (pg/ml·180 min) & 10635.4 & 1336.1 & 11417.8 & 1263.2 & 12883.3 & 1215.1 & 11201.8 & 931.6 \\
\hline
\end{tabular}

Citation: Re R, Pombo S, Calame W, Lefranc-Millot C, Guérin-Deremaux L (2016) The Satiating Effect of NUTRALYS® Pea

Protein Leads to Reduced Energy intake in Healthy Humans. J Nutrition Health Food Sci 4(3): 1-10. D0I: http://dx.doi. 
respectively. However, statistical analysis of GLP-1 AUC found no significant differences between the test products $(p>0.05)$.

Consumption of the test product containing $30 \mathrm{~g}$ pea protein resulted in sustained secretion of CCK reaching a peak of 0.93 $\pm 0.12 \mathrm{ng} / \mathrm{ml}$ at 40 minutes and returned to baseline at 140 minutes whilst, consumption of the control and $15 \mathrm{~g}$ pea protein test product resulted in lower peak CCK concentration (Figure 2c) at 40 minutes and subsequent return to baseline shortly after at 60 minutes. Despite these differences in the CCK secretion profile between test products, statistical comparisons of AUC did not reveal significant differences between any of the products (all $\mathrm{p}>0.05$ ), though a trend for higher CCK levels following $30 \mathrm{~g}$ of pea protein compared to control was observed ( $p=0.056)$.

Analysis of plasma PYY levels revealed that consumption of $30 \mathrm{~g}$ pea protein appeared to delay the peak $(69.37 \pm 5.33 \mathrm{pg} /$ $\mathrm{ml}$ ) to 100 minutes while plasma concentrations peaked earlier at 40 minutes for the $30 \mathrm{~g}$ whey protein $(70.80 \pm 4.92 \mathrm{pg} / \mathrm{ml})$ and control $(76.68 \pm 7.72 \mathrm{pg} / \mathrm{ml}$ (Figure 2e) and returned to baseline by 100 minutes. Differences in AUC values for PYY secretion after the consumption of the test products were not significant $(\mathrm{p}>$ 0.05).

Correlation was analysed between the changes in VAS score with the concentration of various gut peptides (including insulin) and glucose per person. This was performed on basis of a General Estimating Equations Model, applying time-dependent repeated measurements with BMI and gender as confounding factors. It was shown that the concentrations of CCK, GLP-1 and PYY, as well as that of insulin and glucose, were significantly associated with the various VAS scores, except for PYY and the VAS question "How full do you feel?" ( $p>0.10$ ). Correlations were found to be positive with the question: "How full do you feel?" and negative for the questions "How hungry are you?", "How much do you think you can eat?", and "How strong is your desire to eat?". It is clear that all peptides associate strongly with feelings of being satiated. This agrees with findings by Lemmens et al. [33], despite the differences in VAS questions asked between both studies. Unfortunately, in the present study ghrelin was not evaluated.

\section{Discussion}

This study was designed to assess the satiating effects of two doses of NUTRALYS $®$ pea protein $(30 \mathrm{~g}$ and $15 \mathrm{~g}$ ) when consumed in a vegetable soup, compared to a control soup with no added protein and a soup with $30 \mathrm{~g}$ of whey protein. Although consumption of the soups containing protein led to a significantly lower energy intake at the ad libitum meal compared to the non-protein control, all protein containing soups were equally satiating, independently of the protein type and amount. This indicates that pea protein is as satiating as the more commonly used, dairy derived whey protein ,However, there are subsequent benefits to replacing animal derived proteins with vegetable proteins such as pea, as it has economic and sustainability advantages, and its production is more beneficial in the reduction of global warming, eutrophication, acidification and land use [28]. NUTRALYS $®$ pea protein also has a similar digestibility as animal and dairy protein [23], as such metabolic responses could be hypothesized to be similar.
When looking at metabolic responses, the three soups with added protein resulted in reduced glycaemic and insulinaemic responses compared to the control soup, which might explain their effects on energy intake at the ad libitum meal. The control soup yielded the highest insulin levels throughout the study period, followed by the soup with $15 \mathrm{~g}$ of pea protein, which had the second lowest level of protein and second highest level of carbohydrate. Insulin levels following the soup with $30 \mathrm{~g}$ of pea protein were significantlylowerthan $15 \mathrm{~g}$ of pea protein,suggesting there is potential to replace carbohydrates with proteins in the control of glycaemia and insulinaemia. However, further studies are needed to better evaluate the most appropriate dosage of pea protein to be used for an optimal result, since dose effects were not seen for energy intake at the test meal in the present study. The two products containing $30 \mathrm{~g}$ of protein resulted in the lowest levels of insulin release, which is consistent with the low levels of carbohydrate in these products. Previously it has been reported that protein consumed with carbohydrate can stimulate postprandial insulin responses and lower blood glucose levels $[34,35,36]$ and that meals yielding low blood glucose values can reduce satiety and increase subsequent energy intake [37, 38]. These reports do not fit with the findings in the present study probably because the different levels of carbohydrate in the test soups, used to adjust and harmonize their respective caloric value, are likely to have masked any effects of protein on insulin release. The present results also contrast with that of previous studies, which report that a difference in protein source does not result in a significant difference in insulin responses [8] or that pea protein hydrolysates result in significantly elevated glucose compared to whey protein [21]. Previous research has also indicated that pea protein modulates CCK and GLP-1 levels [39], but in the present study differences in AUC between the test products, including the control, were not statistically significant for PYY, GLP-1 or CCK. A trend to significance was observed in the $30 \mathrm{~g}$ pea protein group for CCK evaluation. As such, there is not sufficient evidence to agree with the previous research, that pea protein modulates CCK and GLP-1 levels. As pea and whey did not differ in their satiety related endocrine post-prandial response, the endocrine response agrees with ad libitum meal intake, however if the control is also considered, an endocrinal mechanism for the decreased ad libitum energy intake in protein containing test products, cannot be drawn in this study. Nevertheless, interpretation of satiety hormone results should consider these samples were acquired from a small subset of participants, thus potentially resulting in insufficient statistical power and high variation between levels of these hormones across participants.

Endocrinal response is typically mediated by protein digestion factors, such as amino acid type and rate of uptake. Despite whey protein being considered a fast protein [11] and NUTRALYS ${ }^{\circledR}$ pea protein a fast-intermediate protein [40], in terms of the speed of which dietary amino acids are absorbed by the gut, ad libitum meal findings indicated that pea protein was as satiating as whey protein.

Due to the presence of branched chain amino acids in whey protein [22], quicker release of amino acids, such as leucine with known satiating capability, can be assumed, in comparison to pea 
protein. However as shown, this did not lead to greater satiety, despite significantly lower subjective hunger ratings for the soup containing whey protein. Additionally, the effect of bioactive peptides that might be present in legumous vegetables, such as peas [39],or their digestive derivatives, which affect digestion and satiety by suppressing negative feedback from pancreatic secretions, for example through increased CCK release [41], should be considered. Although, interestingly, there was a near significant trend for higher CCK levels following the soup with $30 \mathrm{~g}$ pea protein, which might be attributed to such an effect, it did not affect ad libitum meal intake in comparison to whey. However, if a link between NUTRALYS $®$ pea protein and ad libitum meal intake reduction through bioactive peptides could be established through further research, this mechanism could be exploited within this protein type and developed for use in future nutraceutical applications [39].

In regards to subjective measures of food intake, VAS scores indicated that all four test products affected feelings of food intake differently, with the differences in subjective responses not necessarily aligning with behavior at the ad libitum meal. This highlights the inadequacies of only using subjective measures in satiety assessment, which was particularly highlighted by $30 \mathrm{~g}$ pea protein test product being perceived to be significantly more filling than $15 \mathrm{~g}$ of pea protein, yet while the intake at the ad libitum meal did not significantly change. Additionally, in comparison to the literature, in this study $30 \mathrm{~g}$ whey protein significantly increased subjective rates of prospective consumption and decreased subjective rates of hunger over that of $30 \mathrm{~g}$ pea protein, however previous studies have reported that pea hydrolysate has a greater effect on reducing subjective ratings of appetite than milk proteins [21]. In the current study and other work assessing the effect of pea and milk proteins on satiety, no differences in ad libitum intake have been shown $[21,42]$. Although when highlighting supporting literature, the food model and the context in which it was consumed must be considered when evaluating subjective measures, it is evident that in the assessment of a proteins effect on satiety, ad libitum intake measures must be considered the standard.

To the best of our knowledge, this is the only study to compare the satiating capability of this type of pea protein with whey, and although we were able to demonstrate that the consumption of NUTRALYS $®$ pea protein in either a $30 \mathrm{~g}$ or $15 \mathrm{~g}$ portion can beneficially result in reduced energy intake at next meal, and to the same degree as whey protein, limitations within the present study were highlighted. For instance, analysis of the appetite hormone response in a larger cohort, than in the present study $(n=9)$, would have produced findings with greater statistical power. Using a larger cohort for the measurement of endocrine responses, may have therefore reduced the variability of the data set and as such provide a clearer understanding of the endocrinal response to the test products. Furthermore, as pea and whey protein act as fast-intermediate and fast proteins, respectively, examining the satiating effects of pea and whey protein over a longer time duration and determining if reduced energy intake at the ad libitum meal is compensated for at a later meal, would be of interest. This would also provide insight into the amino acid uptake rate in relation to food consumption, for the development of weight management strategies [43], which require a sustained reduced food intake beyond that of one meal. In addition, to promote adoption of pea protein over that of whey for satiety, understanding effects on food intake in other populations other than "healthy" such as overweight or obese would be beneficial to establish.

\section{Conclusion}

The present study has shown that pea protein enhances satiety with positive impact on energy intake to the same extent as the more commonly used, dairy derived, whey protein. As there is a real and urgent need to find healthy alternatives to animal sources of proteins, mainly, but not only, for environmental reasons, pea proteins bring high advantages in such a context. As plant-based proteins have been less studied as for their metabolic and organic becoming, more work is needed to explore further the mechanisms and effectiveness of pea protein in various populations and investigate implications of its incorporation into commercial available products.

\section{Declarations}

Conflict of interest: The authors declare that this study was supported by a grant from Roquette, France.

Ethical approval and Clinical trial registration: The study was submitted to Kent Research Ethics Committee and was granted a favorable ethical opinion (REC reference: 11/ LO/0642).The study was conducted, in accordance with ICHGCP guidelines. The study was explained to the participants and informed consent was obtained.

\section{Reference}

1. Jensen CD, Sato AF, Jelalian E. Obesity: Causes and Consequences. In Encyclopedia of Behavioral Medicine. 2013:1355-1358. 10.1007/9781-4419-1005-9_767.

2. Norton I, Moore S, Fryer P. Understanding food structuring and breakdown: engineering approaches to obesity. Obesity Reviews. 2007;8 Suppl 1:83-88.

3. Blundell J. Making claims: functional foods for managing appetite and weight. Nature Reviews Endocrinology. 2010;6(1):53-56. doi: 10.1038/ nrendo.2009.224.

4. Van Kleef E1, Van Trijp JC, Van Den Borne JJ, Zondervan C. Successful development of satiety enhancing food products. Towards a multidisciplinary agenda of research challenges. Critical Review in Food Science and Nutrition. 2012;52(7):611-628. doi: 10.1080/10408398.2010.504901.

5. Abete I, Astrup A, Martínez JA, Thorsdottir I, Zulet MA. Obesity and the metabolic syndrome: role of different dietary macronutrient distribution patterns and specific nutritional components on weight loss and maintenance. Nutr Rev. 2010;68(4):214-231. doi: 10.1111/ j.1753-4887.2010.00280.x.

6. Bowen J, Noakes M, Clifton PM. Appetite regulatory hormone responses to various dietary proteins differ by body mass index status despite similar reductions in ad libitum energy intake. J Clin Endocrinol Metab. 2006;91(8):2913-2919. 
7. Anderson GH, Tecimer SN, Shah D, Zafar TA. Protein source, quantity, and time of consumption determine the effect of proteins on shortterm food intake in young men. J Nutr. 2004;134(11):3011-3015.

8. Lang V, Bellisle F, Oppert JM, Craplet C, Bornet FR, Slama G, Guy-Grand B. Satiating effect of proteins in healthy subjects: a comparison of egg albumin, casein, gelatin, soy protein, pea protein, and wheat gluten. American Journal of Clinical Nutrition. 1998;67(6):1197-1204.

9. Uhe AM, Collier GR, O'Dea K. A comparison of the effects of beef, chicken and fish protein on satiety and amino acid profiles in lean male subjects. Journal of Nutrition. 1992;122(3):467-472.

10. Hall WL, Millward DJ, Long SJ, Morgan LM. Casein and whey exert different effects on plasma amino acid profiles, gastrointestinal hormone secretion and appetite. British Journal of Nutrition. 89(2):239-248.

11. Veldhorst M1, Smeets A, Soenen S, Hochstenbach-Waelen A, Hursel R, Diepvens K, et al. Protein-induced satiety: effects and mechanisms of different proteins. Physiology and Behavior. 94(2):300-307. doi: 10.1016/ j.physbeh.2008.01.003.

12. Mellinkoff SM, Frankland M, Boyle D, Greipel M. Relationship between serum amino acid concentration and fluctuations in appetite. Journal of Applied Physiology. 1956;8(5):535-538.

13. Floyd JC Jr, Fajans SS, Conn JW, Knopf RF, Rull J. Stimulation of insulin secretion by amino acids. J Clin Invest. 1966;45(9):1487-1502.

14. Nilsson M, Stenberg M, Frid AH, Holst JJ, Björck IM. Glycemia and insulinemia in healthy subjects after lactose-equivalent meals of milk and other food proteins: the role of plasma amino acids and incretins. American Journal of Clinical Nutrition. 2004;80(5):1246-1253.

15. Lynch CJ, Gern B, Lloyd C, Hutson SM, Eicher R, Vary TC. Leucine in food mediates some of the postprandial rise in plasma leptin concentrations. American Journal of Physiology -Endocrinology and Metabolism. 2006;291(3):E621-630.

16. Hochstenbach-Waelen A, Westerterp-Plantenga MS, Veldhorst MA, Westerterp KR. Single-protein casein and gelatin diets affect energy expenditure similarly but substrate balance and appetite differently in adults. J Nutr. 2009;139(12):2285-2292. doi: 10.3945/ jn.109.110403.

17. Lam DD, Przydzial MJ, Ridley SH, Yeo GS, Rochford JJ, O'Rahilly S, Serotonin 5-HT2C receptor agonist promotes hypophagia via downstream activation of melanocortin 4 receptors. Endocrinology. 2008;149(3):1323-1328.

18. Bassil MS, Hwalla N, Obeid OA. Meal Pattern of Male Rats Maintained on Histidine-, Leucine or Tyrosine-Supplemented Diet. Obesity. 2007;15(3):616-623.

19. Morimoto T, Yamamoto Y, Yamatodani A. Brain histamine and feeding behavior. Behav Brain Res. 2001;124(2):145-150.

20. Dangin M, Boirie Y, Garcia-Rodenas C, Gachon P, Fauquant J, Callier P, et al. The digestion rate of protein is an independent regulating factor of postprandial protein retention. American Journal of Physiology: Endocrinology and Metabolism. 2001;280(2):E340-348.

21. Diepvens K, Häberer D, Westerterp-Plantenga M. Different proteins and biopeptides differently affect satiety and anorexigenic/orexigenic hormones in healthy humans. Int J Obes (Lond). 2008;32(3):510-518. doi: $10.1038 /$ sj.ijo.0803758.

22. Gilbert JA, Bendsen NT, Tremblay A, Astrup A. Effect of proteins from different sources on body composition. Nutr Metab Cardiovasc Dis. 2011;21Suppl 2:B16-31. doi: 10.1016/ j.numecd.2010.12.008.
23. Huiman Yang, Laetitia Guérin-Deremaux, Leon Zhou, Amy Fratus, Daniel Wils, Charlie Zhang, et al. Evaluation of nutritional quality if a novel pea protein. AgroFood Industry hi-tech. 2012;23(6):8-10.

24. Swiatecka D, Swiatecki A, Kostyra H, Marciniak-Darmochwał K, Kostyra E. The impact of pea protein hydrolysates on bacterial physiological activity-An in vitro study. International Journal of Food Microbiology. 2010;140(2-3):263-270. doi: 10.1016/ j.ijfoodmicro.2010.03.015.

25. Rigamonti E, Parolini C, Marchesi M, Diani E, Brambilla S, Sirtori CR, et al. Hypolipidemic effect of dietary pea proteins: Impact on genes regulating hepatic lipid metabolism. Molecular Nutrition \& Food Research. 2010;54 Suppl 1:S24-30. doi: 10.1002/mnfr.200900251.

26. Barbana C, Boye J.I. Angiotensin I-converting enzyme inhibitory activity of chickpea and pea protein hydrolysates. Food Research International. 2010;43(6):1642-1649. DOI: 10.1016/j.foodres.2010.05.003.

27. Li H1, Prairie N, Udenigwe CC, Adebiyi AP, Tappia PS, Aukema HM, et al. Blood pressure lowering effect of a pea protein hydrolysate in hypertensive rats and humans. Journal of Agricultural and Food Chemistry. 2011;59(18):9854-9860. doi: 10.1021/ jf201911p.

28. Davis J, Sonesson U, Baumgartner DU, Nemecek T. Environmental impact of four meals with different protein sources: case studies in Spain and Sweden. Food Research International. 2010;43(7):18741884. Doi: 10.1016/j.foodres.2009.08.017.

29. Morgan JF, Reid F, Lacey JH. The SCOFF questionnaire: assessment of a new screening tool for eating disorders. British Medical Journal. 1999;319(7223):1467-1468.

30.van Strien T, Frijters JE, Bergers G, Defares PB. The Dutch Eating Behavior Questionnaire (DEBQ) for assessment of restrained, emotional, and external eating behavior. International Journal of Eating Disorders. 1986;5(2):295-315. 10.1002/1098-108X(198602) 5:23.0.CO.

31. Hull S, Re R, Tiihonen K, Viscione L, Wickham M. Consuming polydextrose in a mid-morning snack increases acute satiety measurements and reduces subsequent energy intake at lunch in healthy human subjects. Appetite. 2012;59(3):706-712. doi: 10.1016/j.appet.2012.08.004.

32. Rosner B. Fundamentals of biostatistics. Pacific Grove, CA:: Duxbury. 2000.

33.Lemmens SG, Martens EA, Kester AD, Westerterp-Plantenga MS. Changes in gut hormone and glucose concentrations in relation to hunger and fullness. American Journal of Clinical Nutrition. 2011;94(3):717-725. doi: 10.3945/ajcn.110.008631.

34. Gannon MC, Nuttall FQ, Saeed A, Jordan K, Hoover H. An increase in dietary protein improves the blood glucose response in persons with type 2 diabetes. American Journal of Clinical Nutrition. 2003;78(4):734-741.

35. Layman DK, Shiue H, Sather C, Erickson DJ, Baum J. Increased dietary protein modifies glucose and insulin homeostasis in adult women during weight loss. Journal of Nutrition. 2003;133(2):405-410.

36. Karamanlis A, Chaikomin R, Doran S, Bellon M, Bartholomeusz FD, Wishart JM, et al. Effects of protein on glycemic and incretin responses and gastric emptying after oral glucose in healthy subjects. American Journal of Clinical Nutrition. 2007;86(5):1364-1368.

37. Ludwig DS, Majzoub JA, Al-Zahrani A, Dallal GE, Blanco I, Roberts SB.High glycemic index foods, overeating, and obesity. Pediatrics. 1999;103(3):E26. 
38. Alfenas RC, Mattes RD. Influence of glycemic index/load on glycemic response, appetite, and food intake in healthy humans. Diabetes Care. 2005;28(9):2123-2129.

39. Roy F, Boye J, Simpson B. Bioactive proteins and peptides in pulse crops: Pea, chickpea and lentil. Food Research International. 2010;43(2):432-442.

40. Overduin J, Guérin-Deremaux L, Wils D, Lambers TT. NUTRALYS pea protein: characterization of in vitro gastric digestion and in vivo gastrointestinal peptide responses relevant to satiety. Food Nutr Res. 2015;59:25622. doi: 10.3402/ fnr.v59.25622.
41. Guillamon E, Pedrosa M.M, Burbano C, Cuadrado C, de Cortes Sanchez M, Muzquiz M. The trypsin inhibitors present in seed of different grain legume species and cultivar. Food Chemistry. 2008;107:68-74.

42. Häberer D, Tasker M, Foltz M, Geary N, Westerterp M, Langhans W. Intragastric infusion of pea-protein hydrolysate reduces test-meal size in rats more than pea protein. Physiol Behav. 2011;104(5):10411047. doi: 10.1016/ j.physbeh.2011.07.003.

43. Hetherington MM1, Cunningham K, Dye L, Gibson EL, Gregersen NT, Halford JC, et al. Potential benefits of satiety to the consumer: scientific considerations. Nutr Res Rev. 2013;26(1):22-38. doi: 10.1017/ S0954422413000012. 